\title{
Screening of Ethanolic Extracts of Medicinal Herbal Drugs Against Oral Microbes
}

\author{
Harsha $L^{1}$, Lakshmi Thangavelư ${ }^{2}$
}

Harsha L ${ }^{1}$, Lakshmi Thangavelu ${ }^{2}$

'Bachelor of Dental College and

Hospitals, Saveetha Dental College and Hospitals, Chennai INDIA.

2Department of Pharmacology,

Saveetha Dental College and Hospitals,

Chennai INDIA.

\section{Correspondence}

Lakshmi Thangavelu

Assistant Professor, Department of Pharmacology, Saveetha Dental College, Chennai, INDIA.

Phone no: 91-044-26800152

E-mail: lakshmi085@gmail.com

\section{History}

- Submission Date: 03-08-2016;

- Review completed: 22-9-2016;

- Accepted Date: 30-10-2016.

DOI : 10.5530/pj.2017.2.33

Article Available online

http://www.phcogj.com/v9/i2

\section{Copyright}

(C) 2017 Phcog.Net. This is an openaccess article distributed under the terms of the Creative Commons Attribution 4.0 International license.

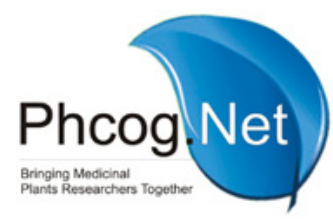

\begin{abstract}
Aim: The aim of the present study is to screen the ethanolic extracts of medicinal herbal drugs against oral microbes. Objective: In this study, 3 medicinal herbs were evaluated for antimicrobial activity against five common oral bacteria as a screen for potential candidates for the development of natural antibiotics. Methods: Ethanolic extracts of medicinal herbs were tested for activity against Enterococcus faecalis, Lactobacillus acidophilus, Streptococcus mutans, and Streptococcus sanguis grown in brain heart infusion (BHI) broth. A broth microdilutionassay was used to determine the minimum inhibitory concentration (MIC) and minimum bactericidal concentration (MBC). A disk diffusion assay was performed by inoculating bacterial cultures on $\mathrm{BHI}$ agar plates with paper disks soaked in each of the medicinal herb extracts. Results: The ethanolic extracts of many of the 3 medicinal herbs showed antimicrobial activity against the five types of pathogenic oral bacteria. The extracts of Caralluma fimbriata, Hemidesmus indicus, and Grape seed effectively inhibited the growth of oral bacteria and showed distinct bactericidal activity. Conclusion: These results suggest that alternative medicines with proven antimicrobial effects, such as Caralluma fimbriata, Hemidesmus indicus, and Grape seed may be useful for the treatment of dental diseases.
\end{abstract}

Key words: Anti cariogenic, Dental caries, Natural products Pathogenic, Oral bacteria.

\section{INTRODUCTION}

Natural products have been used for thousands of years in Dental practice for the management of dental infections. Oral bacteria are the primary etiologic agents that cause dental caries/plaque. ${ }^{1}$ Dental plaque plays the primary role in the pathogenesis of the dental caries. Dental plaque is a general term for the diverse microbial community found on the tooth surface, embedded in a matrix of polymers of bacterial and salivary origin. Plaque is found preferentially at protected and stagnant surfaces, and these are at the greatest threat of disease. ${ }^{1}$

Caralluma fimbriata is an edible perennial herb grown in dry parts of Tamil Nadu, India. ${ }^{2}$ It belongs to family Asclepiadaceae. ${ }^{3}$ It is well-known as famine food, appetite suppressant and thirst quencher. ${ }^{4}$ The stem of the plant is widely used to treat several ailments including diabetes, rheumatism, leprosy, peptic ulcer, inflammation, jaundice, dysentery, constipation, stomach pain, hepatitis B and C..$^{5}$ It is listed in The wealth of India (1992) as a medicinal plant used for diabetes, rheumatism, leprosy, peptic ulcer, inflammation, jaundice, dysentery, constipation, stomach pain, hepatitis B and C.,7

Phytochemicals in fruits, vegetables, spices and traditional herbal medicinal plants play a protective role against many human chronic diseases including cancer and cardiovascular disease (CVD).$^{5-7}$ On inves- tigation, the phytochemicals discovered are flavone glycosides, pregnane glycosides, lupeol, megastigmane glycosides, bitter principles, saponins, various flavonoids. ${ }^{8,36}$ The plant possess beneficial effects as antihyperglycemic, antibacterial, antifungal, antinociceptive and antiproliferative activities. ${ }^{3}$

Caralluma fimbriata has potent resistance against fungal attack and hence can be used for the management of skin infections.

Grape seed extract has shown a wide variety of beneficial action when used as a dietary supplement. it contains proanthocyanidin which provides the antioxidant property in the extract. ${ }^{9}$ It has a grater action towards free radical scavenging, on comparison to others such as vitamin $\mathrm{C}$ and E. ${ }^{9}$ Flavanols, flavonols, stilbenes and phenolic acids are the other phenolic compounds present in grape seed extract. ${ }^{10-13}$ These phenolics are mainly distributed in the skin, stem, leaf and seed of grape. ${ }^{14}$ It has antioxidant and free radical scavenging, Anti microbial, Anti diabetic, Immuno modulatory, Anti cariogenic, Hepato protective activity. ${ }^{15}$

Root portion of $H$. indicus is also used in certain conditions like skin diseases, syphilis, elephantiasis, loss of appetite, blood purification and for kidney and urinary disorders and as well as in some biological activities namely hepatoprotective, antioxidant, antithrombotic, anti-ulcerogenic, anti-inflammatory, immunomodulatory. ${ }^{16}$ 


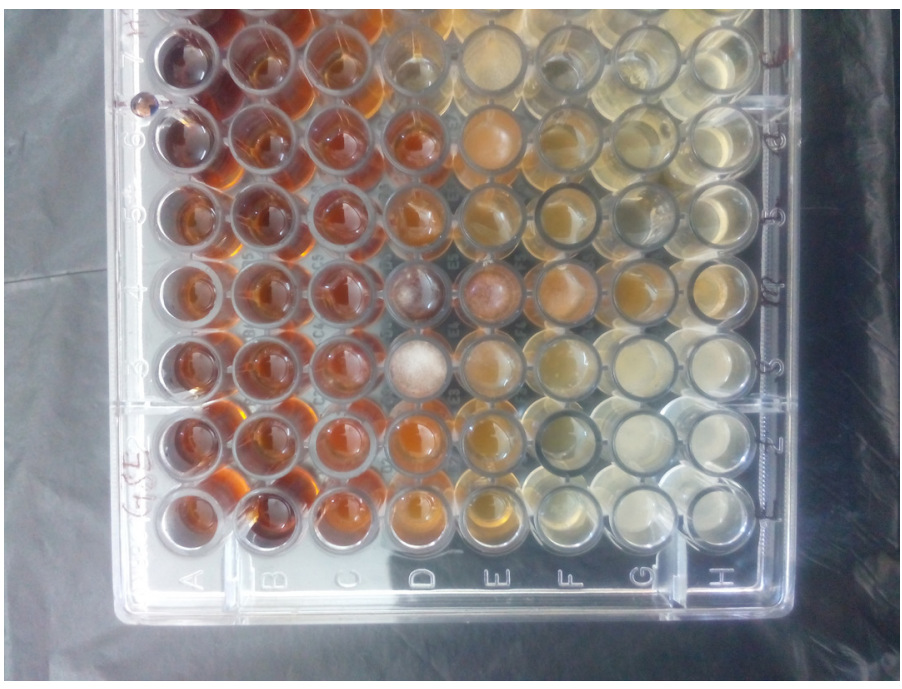

Figure 1: MIC studies of extracts

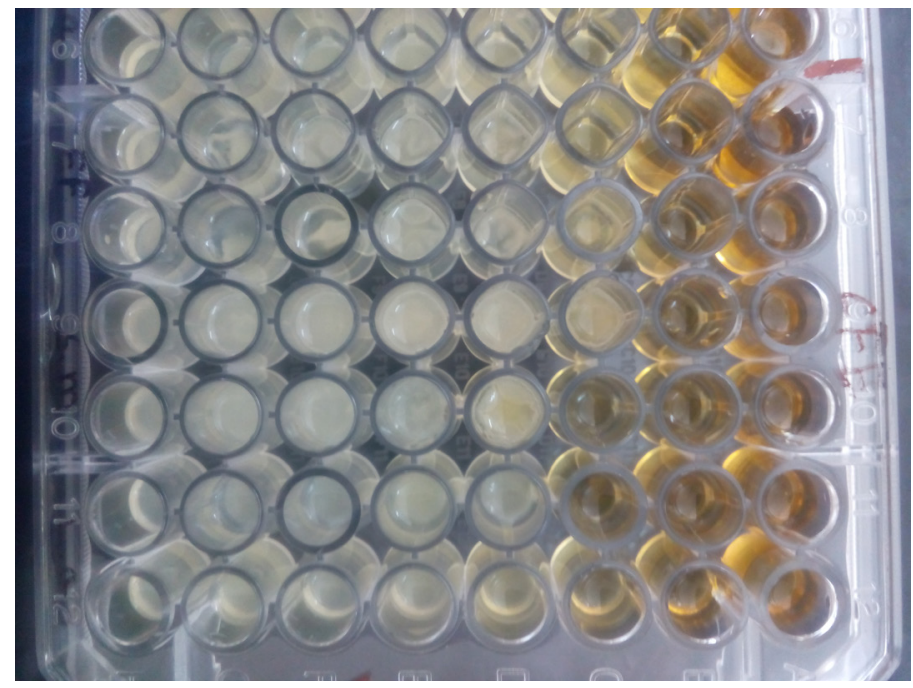

Figure 2: Showing MIC after incubation

\begin{tabular}{|c|c|c|c|c|}
\hline & $\begin{array}{c}\text { S. } \\
\text { Mutans }\end{array}$ & $\begin{array}{c}E . \\
\text { Faccalis }\end{array}$ & S. Sanguis & L. acidophilus \\
\hline Caralluma fimbriata & $25 \mathrm{mg} / \mathrm{ml}$ & $50 \mathrm{mg} / \mathrm{ml}$ & $25 \mathrm{mg} / \mathrm{ml}$ & $50 \mathrm{mg} / \mathrm{ml}$ \\
\hline Hemidesmus indicus & $25 \mathrm{mg} / \mathrm{ml}$ & $50 \mathrm{mg} / \mathrm{ml}$ & $25 \mathrm{mg} / \mathrm{ml}$ & $50 \mathrm{mg} / \mathrm{ml}$ \\
\hline Grape seed extract & $50 \mathrm{mg} / \mathrm{ml}$ & $50 \mathrm{mg} / \mathrm{ml}$ & $25 \mathrm{mg} / \mathrm{ml}$ & $25 \mathrm{mg} / \mathrm{ml}$ \\
\hline
\end{tabular}

\section{MATERIALS AND METHODS}

\section{Drugs}

Grape seed, Hemidesmus indicus, Caralluma fimbriata is obtained from Green chem herbal extracts \& formulations, Bengaluru.

ATCC strains of the chosen microbes were obtained.

\section{S. Mutans - ATCC strain 25175}

S. Sanguis -ATCC strain 10557

\section{Acidophilus -ATCC strain 4356}

E. faecalis- ATCC strain 29212

Medium -Tryptic soy broth -broth dilution method

\section{Minimum inhibitory concentration ${ }^{17-19}$}

To $100 \mu \mathrm{L}$ of sterile broth, $100 \mu \mathrm{g} / \mathrm{ml}$ of the sample was taken as initial concentration in the first well of 96 well titre plates. This was serially diluted to obtain the dilutions of $50 \mathrm{mg} / \mathrm{mL}, 25 \mathrm{mg} / \mathrm{mL}, 15 \mathrm{mg} / \mathrm{mL}$, $10 \mathrm{mg} / \mathrm{mL}, 5 \mathrm{mg} / \mathrm{mL}, 2.5 \mathrm{mg} / \mathrm{mL}$ and finally $1 \mathrm{mg} / \mathrm{mL}$. The study was conducted using 96 well titre plates. Each concentration was inoculated with $0.01 \mathrm{~mL}$ of 24 hours bacterial cell suspension and incubated at $37^{\circ} \mathrm{C}$ for $24 \mathrm{hr}$. The presence of cloudiness or turbidity of the broth indicates positive growth. The concentration at which it inhibits the bacterial growth is considered as the Minimum Inhibitory Concentration (MIC).

\section{RESULT AND DISCUSSION}

In this study, All the three extracts tested at different concentrations show significant antibacterial efficacy. Caralluma fimbriata shows no growth at $25 \mathrm{mg} / \mathrm{ml}$ tested against $S$. mutans and $S$. sanguis, $50 \mathrm{mg} / \mathrm{ml}$ against L. acidophilus and E. faecalis. Hemidesmus indicus showed no growth at $25 \mathrm{mg} / \mathrm{ml}$ against $S$. mutans, S. sanguis and at $50 \mathrm{mg} / \mathrm{ml}$ against E. faecalis, L. acidophilus. Grape seed extract showed No growth at $50 \mathrm{mg} / \mathrm{ml}$ against S. mutans, E. faecalis and at $25 \mathrm{mg} / \mathrm{ml}$ against L. acidophilus, S. sanguis (Fig 1 \& 2).

Disk diffusion assay, zone of inhibition is measured in mm. Grape seed extract showed maximum zone of inhibition $19 \mathrm{~mm}$ against $S$. mutans, and $22 \mathrm{~mm}$ against $L$. acidophillus.

Use of natural medicinal products have become vital in view of their safety. A novel estimate suggests that, in many developing countries people depends on traditional practitioners and medicinal plants to meet primary health care needs.

\section{CONCLUSION}

In conclusion, it is suggested that the signifiacnt antibacterial efficacy of the three extracts found in this study could be attributed due to the presence of polyphenols. However, further clinical trials are required to prove the anticariogenic efficacy.

\section{ACKNOWLEDGEMENT}

The authors are thankful to Greenchem Herbal extracts, Bengaluru and Saveetha Dental College \& Hospitals for kind support.

\section{CONFLICT OF INTEREST}

No conflict of interest are declared.

\section{REFERENCES}

1. Lakshmi T, Aravind KS. International Journal of Botany and Research (IJBR). 2012;1(2):30-40

2. Ivan K, Stjepan P, Danica K. Antifungal activity of fluid extract and essential oil from anise fruits (Pimpinella anisum L., Apiaceae); Acta Pharm. 2005;55(4):37785. PMid:16375827.

3. Bibi Y, Tabassum S, Zahara K, Bashir T, Haider S. Ethnomedicinal and Pharmacological properties of Caralluma tuberculata NE Brown-A review. Pure and Applied Biology. 2015;1;4(4):503.

4. Yazdani D, Rezazadeh SH, Amin GH, Abidin Z, Shahnani S. Antifungal activity of dried extracts of anise (Pimpinella anisum L.) and star anise (Illicium verum Hook. f.) against dermatophyte and saprophyte fungi. Journal of Medical Plants. 2009;8(5):24-9.

5. Packialakshmi N, Naziya S. Screening of antibacterial and phytochemical analysis of Caralluma fimbriata. The Pharma Innovation Journal. 2014;3(6):65-9.

6. Preus HG. Report on the Safety of Caralluma fimbriafa and its Extract.

7. Priya D, Rajaram K, Suresh KP. Phytochemicals studies and GC-MS analysis of Callum's fimbriata. IJPRD. 2011;3(10):105-10.

8. Naingade SS, Jadhav AS, Surve SB. Caralluma fimbriata: An Overview. IJPBS. 2013;3(1):281-6.

9. Leigh, Jacena M. Health benefits of grape seed Proanthocyanidin extract. Nutrition Noteworthy. 2003;6(1). 
10. En-Qin Xia, Gui-Fang deng, Ya-Jun Guo, Hua-Bin Li. Biological activity of polyphenols from grape. Int J Mol Sci. 2010;11:622-46. http://dx.doi.org/10.3390/ ijms11020622; PMid:20386657 PMCid:PMC2852857.

11. Garcia D, Fique MS, Guerra A, Afonso L, Pereira JM, et al. Principal components of phenolics to characterize red Vinho Verde grapes: anthocyanins or noncoloured compounds? Talanta. 2008;75(5);1190-202. http://dx.doi.org/10.1016/j. talanta.2008.01.012; PMid:18585201.

12. Novaka I, Janeiroa P, Serugab M, Oliveira-Brett, A.M. Ultrasound extracted flavonoids from four varieties of Portuguese red grape skins determined by reverse-phase high-performance liquid chromatography with electrochemical detection. Anal Chim Acta. 2008;630(2):107-15. http://dx.doi.org/10.1016/j. aca.2008.10.002; PMid:19012821.

13. Spacil Z, Novakova L, Solich P. Analysis of phenolic compounds by high performance liquid chromatography and ultra performance liquid chromatography. Talanta. 2008;76(1)189-199. http://dx.doi.org/10.1016/j.talanta.2008.02.021; PMid:18585262.

14. Pastrana-Bonilla E, Akoh CC, Sellappan S, Krewer G. Phenolic content and antioxidant capacity of muscadine grapes. J. Agric Food Chem. 2003;51(18):5497-
503. http://dx.doi.org/10.1021/jf030113c ; PMid:12926904.

15. Anandha D, Karthic A, Lakshmi T. In vitro antiarthritic activity of grape seed ethanolic extract. International Journal of Pharmacognosy and Phytochemical Research. 2015;7(5):977-9.

16. Aravind KS, Lakshmi T, Arun AV. In vitro antibacterial activity of Acacia catechu ethanolic leaf extract against selected acidogenic oral bacteria. Research $J$ Pharm and Tech. 2012;5(3);333-6.

17. Jorgenson JH, John T. Susceptibility test methods dilution and disc the diffusion methods. Manual of Clinical Microbiology. vol. 1, 9 edition pg no.1153-1172. ASM Press Washington.

18. Betty AF, Daniel FS, Alice S. Weissfeld. Bailey \& Scott's. Diagnostic Microbiology $11^{\text {th }}$ edition Mosby page no 229-57.

19. Ananthanarayan R, Paniker's Textbook of Microbiology $8^{\text {th }}$ edition. Publishers University Press: Hyderabad 2009:618.

20. Jennifer MA. Determination of Minimum Inhibitory Concentrations. Journal of Antimicrobial Chemotherapy. 2001;48,(SI):5-16.

Cite this Article: Screening of Ethanolic Extracts of Medicinal Herbal Drugs Against Oral Microbes. Harsha L, Lakshmi T. Pharmacogn J. 2017;9(2):201-3. 